Artikel Penelitian

\title{
Hubungan Faktor Risiko Malnutrisi dan Kadar Albumin Serum terhadap Lama Rawat Inap Pasien Kanker Ginekologi
}

\section{Association Between Nutritional Risk Factors and Serum Albumin Level to Length of Stay in Gynecologic Cancer}

\author{
Meirina Dwi $L^{1,2}$, Ari Natalia P $P^{3}$, Eti Poncorini $P^{3}$ \\ ${ }^{1} J u r u s a n$ Gizi Politeknik Kesehatan Kementerian Kesehatan Semarang \\ ${ }^{2}$ Magister Ilmu Gizi Universitas Sebelas Maret Surakarta \\ ${ }^{3}$ Bagian Ilmu Kesehatan Masyarakat Fakultas Kedokteran Universitas Sebelas Maret Surakarta
}

\begin{abstract}
ABSTRAK
Skrining gizi menjadi tahapan awal penentuan risiko malnutrisi dan albumin sebagai salah satu parameter malnutrisi. Keduanya dapat mengidentifikasi status gizi dan menentukan intervensi gizi dalam mencegah komplikasi dan memperpendek masa lama rawat inap. Tujuan penelitian untuk menganalisis hubungan risiko malnutrisi yang diukur menggunakan Malnutrition Screening Tool (MST) dan kadar albumin serum terhadap lama rawat inap pasien kanker ginekologi. Penelitian observasional dengan rancangan kohort prospektif dilakukan pada bulan Februari s.d April 2016. Sebanyak 64 pasien dilakukan skrining risiko malnutrisi menggunakan MST dengan wawancara. Kadar albumin serum dan lama rawat inap dilihat dari catatan medis pasien. MST mampu mendeteksi risiko malnutrisi pada 33 orang (51,6\%) dan tidak berisiko manlutrisi pada 31 orang (48,4\%). Meskipun secara statistik tidak signifikan subjek berisiko malnutrisi meningkatkan lama rawat inap 0,66 kali $(95 \% \mathrm{Cl}=0,29-1,51)$ dan hipoalbumin 1,31 kali $(95 \% \mathrm{Cl}=0,47-3,66)$. Tindakan pembedahan dan status bekerja menjadi faktor yang berperan pada lama rawat inap pasien kanker ginekologi.
\end{abstract}

Kata Kunci: Albumin, lama rawat inap, faktor risiko malnutrisi

\section{ABSTRACT}

Nutrition screening is the first step to determine malnutrition risk, and albumin is a malnutrition status parameter. Both could identify the nutritional status and determine the nutritional interventions for preventing complications and shortening the hospital length of stay. This study aims to analyze the association between malnutrition risk measured using Malnutrition Screening Tool (MST) and serum albumin level to the length of stay of patients in gynecologic cancer. This research was an observational study using prospective cohort study design from February until April 2016. A total of 64 patients were screened for their nutritional risk based on MST by interviewing. Serum albumin level and length of stay were collected from medical records. MST was able to detect the risk of malnutrition in 33 patients (51,6\%) and not at risk of malnutrition in 31 patients (48,4\%). while not statisically significant, malnutrition risk increases the length of stay by 0,66 times $(95 \% \mathrm{Cl}=0,29-1,51)$ and hypo albumin by 1,31 times $(95 \% \mathrm{Cl}=0,47-3,66)$. Surgery intervention and working status are the two significant predictors for lenght of stay in gynecologic cancer patients

Keywords: Albumin, length of stay, nutritional risk

Korespondensi: Meirina Dwi L. Jurusan Gizi Politeknik Kesehatan Kementerian Kesehatan Semarang, Jl. Wolter Monginsidi 115 Pedurungan Semarang Tel. (024)6710378Email:meirinadwilarasati@yahoo.co.id

DOI: http://dx.doi.org/10.21776/ub.jkb.2017.029.04.6 


\section{PENDAHULUAN}

Malnutrisi merupakan interaksi kompleks antara penyakit dan gizi (1). Prevalensi kejadian malnutrisi di rumah sakit bervariasi sekitar 20-68\% (1-5). Malnutrisi di rumah sakit menyebabkan morbiditas dan mortalitas $(3,4,6)$ seperti penurunan kekuatan otot, perlambatan penyembuhan luka, komplikasi paska operasi, peningkatan risiko infeksi nosocomial, penurunan kualitas hidup pasien (7) yang berakibat memperpanjang masa rawat dan menambah biaya perawatan (1,8-13)

Skrining gizi merupakan tahap awal penentuan risiko malnutrisi $(2,10)$ yang idealnya dilakukan pada pasien baru 1x24 jam setelah masuk rumah sakit $(10,14)$. Alat skrining gizi yang digunakan pada pasien dewasa seperti Subjective Global Assessment (SGA), Nutritional Risk Screening 2002 (NRS-2002), Malnutrition Universal Screening Tool (MUST) dan Malnutrition Screening Tool (MST). Kegunaan alat skrining tersebut dievaluasi mampu memprediksi outcome klinis yang relevan seperti komplikasi penyakit, respon perlakuan medis dan length of stay (LOS) (7).

Malnutrisi juga dapat diketahui dari parameter biokimia $(13,15)$. Albumin merupakan salah satu penanda status malnutrisi pada keadaan klinis pasien yang stabil (16). Penelitian Laky et al menunjukkan bahwa konsentrasi serum albumin yang rendah dikaitkan dengan risiko malnutrisi pada pasien kanker ginekologi (17). Serum albumin $<3,5 \mathrm{~g} / \mathrm{dl}$ juga dihubungkan dengan peningkatan komplikasi, lama rawat dan mortalitas selama di rumah sakit $(13,16)$.

Kanker dikaitkan pula dengan risiko malnutrisi di rumah sakit (18) karena kegananasan penyakit dan penatalaksanaan kanker yang dapat menurunkan asupan makan akibatnya berkontribusi terhadap penurunan berat badan dan terjadinya malnutrisi (19). Risiko malnutrisi pada pasien kanker sebesar 1,509 kali lebih tinggi (3). Mengingat seriusnya dampak malnutrisi pada pasien kanker yang terjadi di rumah sakit maka perlu dilakukan skrining dan penilaian status gizi awal pasien baru yang akan menjalani rawat inap di rumah sakit untuk mengevaluasi status gizi, mengidentifikasi malnutrisi dan menentukan intervensi gizi berdasarkan permasalahan gizi yang dialami pasien $(6,19)$. Salah satu penilaian status gizi tersebut menggunakan parameter biokimia. Penelitian Chen et al, berdasarkan data NRS dan pemeriksaan biokimia menunjukkan risiko malnutrisi 2,3 kali lebih tinggi pada indeks biokima yang abnormal (8). Pentingnya pemeriksaan biokimia dapat dijadikan indikasi adanya malnutrisi yang membutuhkan terapi gizi lebih lanjut (20).

Tujuan penelitian ini menganalisis hubungan risiko malnutrisi yang diukur menggunakan MST dan kadar albumin terhadap lama rawat inap pasien kanker ginekologi. Metode MST dipilih sebagai salah satu alat skrining gizi yang relatif sederhana, cepat, valid dan fleksibel untuk mengidentifikasi pasien yang mempunyai risiko malnutrisi dengan tingkat sensitivitas dan spesifisitas paling tinggi dibandingkan dengan skor SGA bila dibandingkan dengan metode skrining lainnya (21). Hal tersebut didukung penelitian sebelumnya yang menunjukkan peningkatan cakupan jumlah pasien yang terskrining menggunakan metode MST sebesar 34,4\% dibandingkan dengan penggunaan metode SGA sehingga MST dinilai lebih efektif, efisien dan aplikatif (22).

\section{METODE}

Penelitian ini merupakan penelitian observasional dengan rancangan kohort prospektif pada pasien kanker ginekologi sejak Februari s.d April 2016 di salah satu rumah sakit pendidikan di Jawa Timur. Populasi dalam penelitian ini adalah semua pasien kanker ginekologi di Ruang Rawat Inap Obstetri Ginekologi. Subjek penelitian adalah pasien rawat inap yang memenuhi kriteria inklusi diagnosa masuk rumah sakit yaitu kanker terkait ginekologi seperti kanker ovarium, serviks, vulva, vagina, endometrium dan alat kelamin perempuan lainnya, bersedia menjadi subjek dengan menandatangani surat kesediaan menjadi subjek penelitian, mampu berkomunikasi dan kooperatif. Kriteria eksklusinya adalah pasien didiagnosa masuk rumah sakit kanker dengan kemoterapi rutin, pasien dirujuk, pindah perawatan, pulang atas permintaan sendiri dan meninggal dunia selama penelitian. Teknik pengambilan subjek menggunakan purposive sampling. Jumlah subjek minimal yang dibutuhkan untuk setiap kelompok sebagai kelompok terpapar (berisiko malnutrisi) dan subjek tidak terpapar (tidak berisiko malnutrisi) sebesar masingmasing 25 orang. Perkiraan adanya jumlah subjek yang hilang selama penelitian maka jumlah subjek yang dibutuhkan masing-masing 28 orang sehingga subjek minimal keseluruhan berjumlah 56 orang.

Variabel yang diteliti adalah variabel bebas untuk risiko malnutrisi dan kadar albumin serum, sedangkan variabel terikat adalah lama rawat inap serta faktor lain dalam karakteristik subjek seperti usia, pendidikan, pekerjaan, kelas perawatan dan tindakan medis. Risiko malnutrisi merupakan hasil penilaian skrining gizi yang dilakukan dengan wawancara langsung menggunakan formulir MST. MST terdiri dari dua pertanyaan yaitu kehilangan berat badan yang tidak diharapkan dan penurunan nafsu makan yang telah divalidasi digunakan untuk pasien umum, pembedaaan, dan kanker (23). Kehilangan berat badan pada metode skrining MST diukur dengan skoor berikut, jika kehilangan berat badan 1 sampai $5 \mathrm{~kg}$, maka diberi skor $1 ; 6$ sampai $10 \mathrm{~kg}$, maka diberi skor $2 ; 11$ sampai $15 \mathrm{~kg}$ diberi skor 3; lebih dari $15 \mathrm{~kg}$ maka diberi skor 4; dan jika raguragu dalam mengidentifikasi kehilangan berat badan diberi skor 2. Adanya penurunan nafsu makan diberikan skor 1 . Kesimpulan hasil skrining yaitu pasien dengan kategori risiko malnutrisi, jika jumlah skor lebih atau sama dengan 2 , maka disimpulkan pasien mengalami risiko malnutrisi (21).

Kadar albumin serum dan lama rawat dilihat dari catatan medis pasien. Bila albumin $<3,0 \mathrm{~g} / \mathrm{dl}$ disebut hipoalbumin. Lama rawat merupakan lamanya hari pasien dirawat di rumah sakit yang dihitung dari selisih tanggal keluar dengan tanggal masuk rumah sakit diperoleh dari catatan medis pasien dengan kategori $>6$ hari disebut panjang dan $\leq 6$ hari pendek. Karakteristik subjek merupakan data kategorikal. Usia dibedakan menjadi dewasa dan lanjut usia ( $\geq 60$ tahun). Kelas perawatan dibedakan menjadi kelas 1, 2, dan kelas 3. Pendidikan dasar merupakan subjek yang tidak sekolah, tamatan SD dan SMP sedangkan pendidikan lanjut merupakan tamatan SMA dan perguruan tinggi. Pekerjaan dibedakan menjadi bekerja (baik swasta, wiraswasta, petani, buruh maupun pegawai negeri) sedangkan tidak bekerja merupakan subjek ibu rumah tangga. Tindakan medis dibedakan pembedahan dan tanpa pembedahan. Pembedahan merupakan tindakan operasi minor pada organ reproduksi subjek 
seperti surgical staging, radical hysterectomy, radical vulcectomy dan biopsi.

Variabel dianalisis secara deskriptif menggunakan tabel distribusi frekuensi dan prosentase untuk mengetahui karakteristik subjek penelitian, hasil skrining gizi, kadar albumin serum dan lama rawat inap. Analisis bivariat dilakukan untuk mengidentifikasi ada atau tidaknya hubungan antara variabel bebas dengan variabel terikat dan variabel perancu dengan variabel terikat. Uji statistik yang digunakan adalah chi-square dengan confident interval (Cl) 95\% dan tingkat kemaknaan pada penelitian ini ditetapkan dengan nilai $p<0,05$. Besarnya pengaruh risiko malnutrisi, hasil pemeriksaan albumin dan faktor lain terhadap lama rawat inap diketahui dari nilai risiko relatif (RR). Analisis multivariat menggunakan uji statistik regresi logistik untuk mengendalikan faktor perancu seperti usia dan tindakan medis yang diperkirakan berpengaruh terhadap variabel terikat sebagai outcome dan melihat variabel mana yang paling besar pengaruhnya terhadap outcome. Penelitian ini telah memperoleh ethical clearance dari Komisi Etik Penelitian Kesehatan RSUD dr. Saiful Anwar Malang.

\section{HASIL}

Subjek penelitian yang memenuhi kriteria sebagai subjek penelitian sebanyak 70 orang. Selama penelitian berlangsung terjadi drop out sebanyak 6 orang, dengan rincian 3 orang meninggal, 2 orang pulang atas permintaan sendiri (pulang paksa) dan 1 orang pindah perawatan sehingga jumlah akhir subjek penelitian sebanyak 64 orang. Subjek berisiko malnutrisi berjumlah 33 orang dan tidak berisiko malnutrisi sebanyak 31 orang. Hubungan karakteristik subjek penelitian dengan risiko malnutrisi tersaji pada Tabel 1.

Secara deskriptif, proporsi risiko malnutrisi menurut usia dan kelas perawatan hampir sama. Mereka yang berpendidikan lanjut, dengan pembedahan, dan bekerja mempunyai proporsi risiko malnutrisi yang lebih besar. Hasil uji menunjukkan bahwa secara statistik tidak ada hubungan yang bermakna antara karakteristik subjek penelitian baik berdasarkan usia, kelas perawatan, pendidikan, pekerjaan dan tindakan medis dengan risiko malnutrisi yang diukur menggunakan alat skining gizi MST karena memiliki nilai $p>0,05$.
Data kadar albumin diperoleh dari hasil pemeriksaan laboratorium dalam catatan medis. Kadar albumin serum subjek penelitian sebagian besar normal $(85,9 \%)$ sebagaimana disajikan pada Tabel 2. Rata-rata hasil pemeriksaan albumin sebesar $3,69 \mathrm{~g} / \mathrm{dl}$ dengan nilai albumin terendah $2,30 \mathrm{~g} / \mathrm{dl}$ dan tertinggi $4,84 \mathrm{~g} / \mathrm{dl}$.

Tabel 2. Distribusi subjek penelitian berdasarkan hasil pemeriksaan albumin

\begin{tabular}{lrrrrrr}
\hline $\begin{array}{l}\text { Kategori Kadar } \\
\text { Albumin Serum }\end{array}$ & \multicolumn{2}{c}{$\begin{array}{c}\text { Jumlah } \\
\mathbf{n}\end{array}$} & $\begin{array}{c}\text { Rata-rata } \\
\mathbf{( g / d l )}\end{array}$ & SD & Minimum & Maksimum \\
\hline Hipoalbumin & 9 & 14,1 & 2,61 & 0,19 & 2,30 & 2,78 \\
Normal & 55 & 85,9 & 3,87 & 0,47 & 3,04 & 4,84 \\
Jumlah & 64 & 100 & 3,69 & 0,62 & 2,30 & 4,84 \\
\hline
\end{tabular}

Lama rawat inap pada penelitian ini adalah 2 hari hingga 19 hari. Rata-rata lama rawat inap diketahui sebesar $5,03 \pm 2,99$ hari. Sebagian besar subjek penelitian dengan lama rawat pendek sebanyak 47 orang $(73,4 \%)$ dan lama rawat panjang sebanyak 17 orang $(26,6 \%)$.

Tabel 3 tersebut menunjukkan bahwa sebagian besar subjek penelitian memiliki rawat inap pendek ( $\leq 6$ hari) baik menurut usia, kelas perawatan, pendidikan, pekerjaan, tindakan medis, risiko malnutrisi dan kadar albumin. Hasil uji statistik menunjukkan tidak ada hubungan yang bermakna antara karakteristik subjek penelitian baik berdasarkan usia, kelas perawatan, pendidikan, pekerjaan dan tindakan medis serta risiko malnutrisi dan kadar albumin dengan lama rawat.

Analisis multivariat menggunakan uji statistik regresi logistik untuk mengendalikan faktor perancu yang diperkirakan berpengaruh terhadap variabel terikat sebagai outcome dengan batasan nilai $p<0,25$ dan nilai RR $>1$. Hasil penelitian menunjukkan bahwa variabel kelas perawatan, pekerjaan dan tindakan medis mempunyai nilai $p<0,25$ sedangkan usia, kelas perawatan dan kadar albumin memiliki nilai $R R>1$ sehingga dimasukkan dalam analisis multivariat.

Tabel 1. Hubungan karakteristik subjek penelitian dengan risiko malnutrisi

\begin{tabular}{|c|c|c|c|c|c|c|c|}
\hline \multirow{2}{*}{ Karakteristik Subjek } & \multicolumn{2}{|c|}{ Berisiko Malnutrisi $(n=33)$} & \multicolumn{2}{|c|}{ Tidak Berisiko Malnutrisi ( $\mathrm{n=31}$ ) } & \multicolumn{2}{|c|}{ Jumlah } & \multirow{2}{*}{$\mathbf{p}$} \\
\hline & n & $\%$ & n & $\%$ & $n$ & $\%$ & \\
\hline \multicolumn{8}{|l|}{ Usia } \\
\hline Dewasa & 26 & 51,0 & 25 & 49,0 & 51 & 100 & 1,000 \\
\hline Lansia & 7 & 53,8 & 6 & 46,2 & 13 & 100 & \\
\hline \multicolumn{8}{|l|}{ Kelas Perawatan } \\
\hline Kelas 1 dan 2 & 11 & 50,0 & 11 & 50,0 & 22 & 100 & 1,000 \\
\hline Kelas 3 & 22 & 52,4 & 20 & 47,6 & 42 & 100 & \\
\hline \multicolumn{8}{|l|}{ Pendidikan } \\
\hline Dasar & 28 & 53,8 & 24 & 46,2 & 52 & 100 & 0,531 \\
\hline Lanjut & 5 & 41,7 & 7 & 58,3 & 12 & 100 & \\
\hline \multicolumn{8}{|l|}{ Pekerjaan } \\
\hline Bekerja & 23 & 46,9 & 26 & 53,1 & 49 & 100 & 0,242 \\
\hline Tidak bekerja & 10 & 66,7 & 5 & 33,3 & 15 & 100 & \\
\hline \multicolumn{8}{|l|}{ Tindakan medis } \\
\hline Pembedahan & 22 & 47,8 & 24 & 52,2 & 46 & 100 & 0,410 \\
\hline Tanpa pembedahan & 11 & 61,1 & 7 & 38,9 & 18 & 100 & \\
\hline
\end{tabular}


Tabel 3 Hubungan variabel penelitian terhadap lama rawat inap

\begin{tabular}{|c|c|c|c|c|c|c|c|c|}
\hline \multirow{2}{*}{ Variabel } & \multicolumn{2}{|c|}{ Panjang (n=17) } & \multicolumn{2}{|c|}{ Pendek $(n=47)$} & \multicolumn{2}{|c|}{ Jumlah } & \multirow{2}{*}{$\begin{array}{c}\text { RR } \\
(95 \% \mathrm{Cl})\end{array}$} & \multirow{2}{*}{$\mathbf{p}$} \\
\hline & $\mathbf{n}$ & $\%$ & $\mathbf{n}$ & $\%$ & $\mathbf{n}$ & $\%$ & & \\
\hline \multicolumn{9}{|l|}{ Usia } \\
\hline Dewasa & 14 & 27,5 & 37 & 72,5 & 51 & 100 & 1,19 & $1,000^{*}$ \\
\hline Lansia & 3 & 23,1 & 10 & 76,9 & 13 & 100 & $(0,40-3,53)$ & \\
\hline \multicolumn{9}{|l|}{ Kelas Perawatan } \\
\hline Kelas 1 dan 2 & 3 & 13,6 & 19 & 86,4 & 22 & 100 & 2,44 & 0,163 \\
\hline Kelas 3 & 14 & 33,3 & 28 & 66,7 & 42 & 100 & $(0,78-7,61)$ & \\
\hline \multicolumn{9}{|l|}{ Pendidikan } \\
\hline Dasar & 13 & 25,0 & 39 & 75,0 & 52 & 100 & 0,75 & $0,718^{*}$ \\
\hline Lanjut & 4 & 33,3 & 8 & 66,7 & 12 & 100 & $(0,30-1,90)$ & \\
\hline \multicolumn{9}{|l|}{ Pekerjaan } \\
\hline Bekerja & 11 & 22,4 & 38 & 77,6 & 49 & 100 & 0,56 & $0,197^{*}$ \\
\hline Tidak bekerja & 6 & 40,0 & 9 & 60,0 & 15 & 100 & $(0,25-1,26)$ & \\
\hline \multicolumn{9}{|l|}{ Tindakan Medis } \\
\hline Pembedahan & 2 & 11,1 & 16 & 88,9 & 18 & 100 & 0,34 & $0,117^{*}$ \\
\hline Tanpa Pembedahan & 15 & 32,6 & 31 & 67,4 & 46 & 100 & $(0,09-1,34)$ & \\
\hline \multicolumn{9}{|l|}{ Risiko Malnutrisi } \\
\hline Berisiko & 7 & 21,2 & 26 & 78,8 & 33 & 100 & 0,66 & 0,474 \\
\hline Tidak berisiko & 10 & 32,3 & 21 & 67,7 & 31 & 100 & $(0,29-1,51)$ & \\
\hline \multicolumn{9}{|l|}{ Kadar Albumin } \\
\hline Hipoalbumin & 3 & 33,3 & 6 & 66,7 & 9 & 100 & 1,31 & $0,689 *$ \\
\hline Normal & 14 & 25,5 & 41 & 74,5 & 55 & 100 & $(0,47-3,66)$ & \\
\hline
\end{tabular}

Keterangan: *Fisher Exact Test

Tabel 4. Analisis multivariat usia, tindakan medis dan hasil pemeriksaan albumin terhadap lama rawat

\begin{tabular}{cccc}
\hline Variabel & $\mathbf{R R}$ & $\mathbf{9 5 \%} \mathbf{C l}$ & $\mathbf{p}$ \\
\hline $\begin{array}{c}\text { Usia } \quad \text { Lansia } \\
\text { Kelas Perawatan } \\
\quad \text { Kelas 3 }\end{array}$ & 0,38 & $0,70-2,1,1$ & 0,271 \\
$\begin{array}{c}\text { Pekerjaan } \\
\quad \text { Tidak bekerja }\end{array}$ & 0,27 & $0,62-1,22$ & 0,090 \\
$\begin{array}{c}\text { Tindakan Medis } \\
\quad \text { Pembedahan }\end{array}$ & 6,87 & $1,07-26,39$ & 0,041 \\
$\begin{array}{c}\text { Kadar albumin } \\
\text { Hipoalbumin }\end{array}$ & 0,43 & $0,08-2,44$ & 0,342 \\
\hline
\end{tabular}

Hasil analisis multivariat menggunakan uji regresi logistik menunjukkan ada hubungan antara pekerjaan dan tindakan medis terhadap lama rawat inap (Tabel 4). Tindakan medis menjadi faktor dominan terhadap lama rawat dilihat dari nilai $R R 6,87$. Hasil regresi logistik juga menunjukkan Square 0,245 yang berarti kelima variabel tersebut mampu menjelaskan lama rawat sebesar $24,5 \%$ dan sisanya yaitu sebesar $75,5 \%$ dijelaskan oleh faktor lain.

\section{DISKUSI}

Metode MST merupakan metode skrining gizi yang sederhana, cepat, valid dan fleksibel untuk mengidentifikasi pasien yang mempunyai risiko malnutrisi. MST dikembangkan berdasarkan pemilihan pertanyaan-pertanyaan skrining gizi dengan tingkat sensitivitas dan spesifisitas paling tinggi dibandingkan dengan skor SGA (21). Peran skrining gizi dalam mendeteksi malnutrisi dapat dijadikan sebagai tindakan awal dalam dukungan nutrisi dan evaluasi pada pasien kanker (24) karena risiko malnutrisi pada pasien kanker sebagai akibat penyakit dan konsekuensi tindakan medis yang diterima (25). Pada penelitian ini menggunakan MST mampu mendeteksi 33 subjek penelitian dengan kategori berisiko malnutrisi $(51,6 \%)$ dan 31 subjek tidak berisiko malnutrisi $(48,4 \%)$. Penelitian ini konsisten dengan penelitian Shaw et al bahwa MST mengidentifikasi pasien kanker yang mengalami malnutrisi sebanyak 52\% (25). Lebih lanjut diungkapkan Shaw et al bahwa MST memiliki sensitivitas yang baik untuk pasien kanker yang menjalani tindakan kemoterapi maupun radioterapi (25).

Sebagian besar subjek lanjut usia mengalami risiko malnutrisi $(53,8 \%)$ namun hasil uji statistik menunjukkan tidak ada hubungan antara usia dengan risiko malnutrisi yang diukur menggunakan MST. Hal tersebut disebabkan rata-rata usia subjek penelitian $49,6 \pm 9,73$ tahun sedangkan risiko malnutrisi meningkat seiring dengan pertambahan usia terutama usia lanjut $(18,26,27)$. Risiko malnutrisi meningkat 1,97 kali pada pasien dengan usia lebih dari 65 tahun (26). Penelitian ini berbeda dengan penelitian Harimawan et al yang menyatakan usia merupakan faktor yang berpengaruh secara bermakna terhadap risiko malnutrisi yang diukur menggunakan SGA (19). Usia merupakan faktor yang mempengaruhi malnutrisi karena semakin tinggi usia maka semakin meningkat risiko malnutrisi, peningkatan komplikasi penyakit, peningkatan perubahan komposisi tubuh (28) dan peningkatan risiko kematian kanker ginekologi $(29,30)$ akibat kondisi fisik, kognitif dan keterbatasan fisiologis tubuh (27). Perbedaan-perbedaan tersebut diduga karena perbedaan populasi, jenis penyakit dan alat ukur risiko malnutrisi yang digunakan.

Variabel lain dalam karakteristik subjek penelitian yang diteliti sebagai faktor risiko malnutrisi adalah kelas perawatan, pendidikan, pekerjaan dan tindakan medis. Pendidikan subjek terbanyak merupakan tamatan sekolah menengah pertama $(40,6 \%)$ dan hanya $18,8 \%$ subjek penelitian merupakan tamatan pendidikan lanjut (SMA dan PT). Keempat variabel tersebut tidak memiliki hubungan yang bermakna terhadap risiko malnutrisi. Hal ini sesuai dengan penelitian Harimawan et al bahwa kelas perawatan tidak berpengaruh terhadap status gizi awal yang diukur menggunakan SGA. Disisi lain Harimawan et al 
menunjukkan bahwa pendidikan dan pekerjaan berpengaruh terhadap status gizi awal yang diukur menggunakan SGA (19). Orang dengan pendidikan rendah cenderung mempunyai kebiasaan buruk terkait kualitas makanan yang dikonsumsi, kurangnya sumber daya keuangan untuk memenuhi kelengkapan asupan zat gizi dan kurangnya pengetahuan terkait pemilihan bahan makanan (30).

Keseluruhan karakteristik subjek penelitian tidak berhubungan dengan risiko malnutrisi. Pelayanan gizi melalui skrining gizi untuk menentukan risiko malnutrisi tidak tergantung pada usia, kelas perawatan, pendidikan, pekerjaan maupun tindakan medis yang akan dijalani subjek karena skrining gizi dilakukan kepada semua pasien baru 24-48 jam setelah pasien masuk RS. Tahapan pelayanan gizi rawat inap diawali dengan skrining/penapisan gizi yang bertujuan untuk mengidentifikasi pasien/klien yang berisiko dan tidak berisiko malnutrisi. Bila hasil skrining gizi menunjukkan pasien berisiko malnutrisi, maka dilakukan pengkajian/assesmen gizi dan dilanjutkan dengan langkah-langkah proses asuhan gizi terstandar oleh dietisien. Pasien dengan status gizi baik atau tidak berisiko malnutrisi, dianjurkan dilakukan skrining ulang setelah 1 minggu. Jika hasil skrining ulang berisiko malnutrisi maka dilakukan proses asuhan gizi terstandar (14).

Albumin sebagai penanda biokimia yang paling umum digunakan untuk menilai status malnutrisi, mencerminkan kekurangan protein (31-33), tingkat keparahan penyakit, perkembangan penyakit dan prognosis kanker $(29,34)$. Hasil pemeriksaan albumin subjek penelitian sebagian besar normal dengan rata-rata hasil pemeriksaan albumin sebesar $3,69 \mathrm{~g} / \mathrm{dl}$. Pemeriksaan albumin dilakukan pada semua subjek penelitian karena albumin menjadi salah satu pemeriksaan penunjang rutin.

Hasil penelitian menunjukkan tidak ada hubungan bermakna antara karakteristik subjek penelitian baik berdasarkan usia, kelas perawatan, pendidikan, pekerjaan dan tindakan medis dengan lama rawat. Hal ini sesuai Peraturan Menteri Kesehatan No. 28 Tahun 2014 tentang Pedoman Pelaksanaan Program Jaminan Kesehatan Nasional bahwa pelayanan kesehatan yang komprehensif (promotif, kuratif dan rehabilitatif) sesuai dengan indikasi medis tidak terikat dengan besaran iuran yang dibayarkan (35). Artinya, pelayanan medis tidak membedakan kelas perawatan pasien dan SOP pelayanan medis tidak membedakan usia, pendidikan, pekerjaan atau tindakan medis terhadap pasien yang akan mempengaruhi lama rawatnya.

Malnutrisi pada saat pasien masuk rumah sakit mengakibatkan pasien tersebut memiliki lama rawat inap yang lebih panjang bila dibandingkan dengan pasien tidak berisiko malnutrisi dan memiliki risiko lebih tinggi mengalami malnutrisi selama perawatan $(7,12,24)$. Hasil uji statistik menggunakan chi-square dengan tingkat kepercayaan $95 \%$ pada penelitian ini menunjukkan bahwa tidak ada hubungan risiko malnutrisi dengan lama rawat inap dengan nilai $p=0,474$ dan $R R \quad 0,66$. Hal tersebut berbeda dengan penelitian Burgos et al (3), Harimawan et al (19) dan Prasetiyo (36). Hal ini diperkirakan karena perbedaaan alat ukur risiko malnutrisi yang digunakan. Penelitian Burgos et al (3) menggunakan NRS-2002, Harimawan et al (19) menggunakan SGA dan NSSA (Nutrition Services Screening Assessment), Prasetiyo (36) menggunakan MNA sedangkan pada penelitian ini menggunakan MST.

Perbedaan kemampuan indikator NRS-2002, SGA, NSSA, MNA dan MST dalam memperkirakan lama rawat inap dapat disebabkan risiko malnutrisi yang diukur menggunakan SGA telah mencakup data pemeriksaan fisik dan riwayat medis. NRS-2002, NSSA dan MNA hanya mencakup riwayat medis sedangkan MST tidak menggunakan indikator riwayat medis maupun pemeriksaan fisik. Nilai RR 0,66 menunjukkan subjek yang berisiko malnutrisi akan memiliki lama rawat 0,66 kali lebih panjang dibandingkan subjek tanpa risiko malnutrisi. Hasil ini lebih kecil dibandingkan penelitian Lim et al bahwa pasien yang berisiko malnutrisi 1,5 kali tinggal lebih lama dibandingkan pasien tanpa risiko malnutrisi setelah mengontrol usia, jenis kelamin dan jenis penyakit (37). Hal ini menunjukkan risiko malnutrisi menggunakan MST kurang mampu menentukan prediksi lama rawat inap pasien kanker ginekologi karena risiko tinggi malnutrisi sering terjadi pada jenis kanker paru, kepala, leher dan saluran pencernaan bawah yang dapat meningkatkan komplikasi pasca operasi, mortalitas dan penurunan kualitas hidup yang berdampak pada lama rawat inap (25). MST memiliki keterbatasan hanya menggunakan kriteria perubahan berat badan dan asupan makan yang bersifat akut sehingga kurang menggambarkan keadaan risiko malnutrisi pada pasien kanker yang cenderung bersifat kronis. Oleh karenanya risiko malnutrisi menggunakan MST untuk pasien kanker ginekologi pada penelitian ini tidak berhubungan dengan lama rawat inapnya.

Albumin juga diduga menjadi salah satu prediktor lama rawat. Analisis bivariat menunjukkan bahwa tidak ada hubungan kadar albumin dengan lama rawat inap ( $R R=1,31, p=0,689,95 \% \mathrm{Cl}=0,47-3,66)$. Hasil penelitian ini serupa dengan penelitian da Silva et al (20). Hal tersebut diperkirakan nilai rata-rata hasil pemeriksaan albumin dalam kategori normal $(3,69 \pm 0,62 \mathrm{~g} / \mathrm{dl})$ sehingga tidak berhubungan dengan lama rawat inap. Rata-rata albumin $<3 \mathrm{~g} / \mathrm{dl}$ berhubungan dengan lama rawat inap dan mortalitas menggunakan batasan tersebut (39). Berbeda dengan penelitian Chen et al (8), Cabrerizo et al (16), Arques et al (39) dan Baghetto et al (13) yang menyebutkan rendahnya serum albumin dihubungkan dengan lama rawat inap dan tingginya mortalitas selama masa rawat inap di rumah sakit karena hipoalbumin merupakan salah satu indikator kegawatan penyakit (15). Meskipun hasil penelitian secara statistik menunjukkan tidak ada hubungan antara albumin dan lama rawat yang signifikan, namun secara praktis albumin pada pasien kanker obstetri ginekologi menjadi pemeriksaan rutin.

Hasil analisis multivariat menggunakan uji regresi logistik menunjukkan ada hubungan antara pekerjaan $(p=0,041$; $R R=5,31)$ dan tindakan medis $(p=0,03 ; R R=6,87)$ terhadap lama rawat inap tetapi berdasarkan analisis bivariat kedua variabel tersebut tidak ada hubungan dengan lama rawat inap. Adanya ketidakkonsistenan antara hasil analisis bivariat dan multivariat ini disebabkan variabel bebas pada analisis bivariat berinteraksi sendiri terhadap variabel terikat sedangkan pada analisis multivariat berinteraksi bersama dengan variabel lain.

Tindakan medis menjadi faktor dominan terhadap lama rawat dilihat dari nilai RR 6,87. Pembedahan minor dapat memperpanjang lama rawat 6,87 kali daripada tanpa pembedahan pada pasien kanker ginekologi. Tindakan pembedahan menjadi salah satu penanda perbaikan 
kesehatan pasien kanker selama perawatan di rumah sakit yang akan mempengaruhi lama rawat pasien disamping jenis trauma atau penyakit, pengobatan, kualitas perawatan pasien dan ketersediaan fasilitas perawatan $(6,7,17)$. Lebih lanjut Wartawan mengungkapkan 5 faktor yang memiliki hubungan bermakna terhadap lama hari rawat pasien yang menjalani pembedahan yaitu diagnosa penyakit, komplikasi operasi, jenis operasi, teknik operasi dan pelaksana operasi (40).

Pekerjaan menjadi faktor dominan lain terhadap lama rawat selain tindakan medis $(R R=5,31)$. Pekerjaan tidak secara langsung mempengaruhi lama hari rawat pasien, namun mempengaruhi cara pasien dalam membayar biaya perawatan. Pekerjaan menentukan penghasilan serta ada atau tidaknya jaminan kesehatan untuk menanggung biaya selama perawatan di rumah sakit (41).

Hasil regresi logistik juga menunjukkan nilai Nagelkerke $R$ Square 0,245 bahwa kelima variabel tersebut mampu menjelaskan lama rawat sebesar $24,5 \%$ dan sisanya yaitu sebesar $75,5 \%$ dijelaskan oleh faktor lain seperti stadium kanker, metastase kanker, komplikasi penyakit dan pemeriksaan hemoglobin mengingat gejala kanker ginekologi salah satunya adalah perdarahan dari jalan lahir. Hal ini menjadi kelemahan dari penelitian ini karena

\section{DAFTAR PUSTAKA}

1. Mercadal-Orfila G, Lluch-Taltavull J, Campillo-Artero C, and Torrent-Quetglas M. Association between Nutritional Risk Based on the NRS-2002 Test and Hospital Morbidity and Mortality. Nutricion Hospitalaria. 2012; 27(4): 1248-1254.

2. Dent E, Chapman IM, Piantadosi C, and Visvanathan R. Performance of Nutritional Screening Tools in Predicting Poor Six-Month Outcome in Hospitalised Older Patients. Asia Pacific Journal of Clinical Nutrition. 2014; 23(3): 394-399.

3. Burgos R, Sarto B, Elio I, et al. Prevalence of Malnutrition and its Etiological Factors in Hospitals. Nutricion Hospitalaria. 2012; 27(2): 469-476.

4. Neelemaat F, Meijers J, Kruizenga H, van Ballegooijen $\mathrm{H}$, and van Bokhorst-de van der Schueren $M$. Comparison of Five Malnutrition Screening Tools in One Hospital Inpatient Sample. Journal of Clinical Nursing. 2011;20(15-16): 2144-2152.

5. Rasmussen $\mathrm{HH}$, Holst $\mathrm{M}$, and Kondrup J. Measuring Nutritional Risk in Hospitals. Clinical Epidemiology. 2010; 2: 209-216.

6. Huang $\mathrm{TH}$, Chi CC, Liu CH, Chang CC, Kuo LM, and Hsieh CC. Nutritional Status Assessed by Scored Patient Generated Subjective Global Assessment Associated with Length of Hospital Stay in Adult Patients Receiving an Appendectomy. Biomedical Journal. 2014; 37(2): 71-77.

7. Gupta D, Vashi PG, Lammersfeld CA, and Braun DP. Role of Nutritional Status in Predicting the Length of Stay in Cancer: A Systematic Review of the Epidemiological Literature. Annals of Nutrition and Metabolism. 2011; 59(2-4): 96-106.

8. Chen ZY, Gao C, Ye T, et al. Association between Nutritional Risk and Routine Clinical Laboratory tidak dilakukan pengambilan data hasil pemeriksaan hemoglobin sehingga tidak dapat mengetahui besar pengaruhnya terhadap lama rawat pasien kanker ginekologi.

Hasil penelitian ini menyimpulkan bahwa tidak ada hubungan risiko malnutrisi menggunakan MST dengan lama rawat inap. Perlu dilakukan penelitian lanjut pengukuran risiko malnutrisi menggunakan alat skrining gizi lainnya yang tidak hanya menggunakan parameter perubahan berat badan dan asupan makan tetapi menggunakan parameter gizi yang objektif (antropometri, biokimia) dan subjektif (perubahan berat badan, asupan makan, gejala gangguan gastrointestinal, perubahan fisik klinis) yang menggambarkan risiko malnutrisi dan memprediksi lama rawat inap pada pasien kanker ginekologi. Prediksi lama rawat inap tidak hanya dilihat berdasarkan hasil risiko malnutrisi, namun asuhan gizi RS yang komprehensif pun menjadi upaya yang diharapkan dapat mencegah kejadian malnutrisi lebih lanjut yang akan berdampak pada lama rawat inap pasien kanker ginekologi. Tidak ada hubungan yang signifikan antara albumin dan lama rawat, namun secara praktis albumin pada pasien kanker ginekologi menjadi pemeriksaan rutin terkait respon inflamasi yang dapat mengganggu sintesis protein hepar.

Measurements and Adverse Outcomes: A Prospective Study in Hospitalized Patients of Wuhan Tongji Hospital. European Journal of Clinical Nutrition. 2015; 69(5): 552-557.

9. Badia-Tahull MB, Cobo-Sacristán S, Leiva-Badosa E, et al. Use of Subjective Global Assessment, PatientGenerated Subjective Global Assessment and Nutritional Risk Screening 2002 to Evaluate the Nutritional Status of Non-Critically III Patients on Parenteral Nutrition. Nutricion Hospitalaria. 2014; 29(2): 411-419.

10. Mueller C, Compher C, Ellen DM, and the American Society for Parenteral and Enteral Nutrition (A.S.P.E.N.) Board of Directors. Nutrition Screening, Assessment, and Intervention in Adults. Journal of Parenteral and Enteral Nutrition. 2011: 35(1); 16-24.

11. Small SR. Dietitian's Use and Perceptions of Nutrition Screening Tools for the Older Adult. [Thesis]. University of Kentucky, Lexington. 2010.

12. Meilyana F, Djais J, dan Garna H. Status Gizi Berdasarkan Subjective Global Assessment sebagai Faktor yang Mempengaruhi Lama Perawatan Pasien Rawat Inap Anak. Sari Pediatri. 2010; 12(3): 162-167.

13. Beghetto MG, Luft VC, Mello ED, and Pollanczyk CA. Accuracy of Nutritional Assessment Tools for Predicting Adverse Hospital Outcomes. Nutricion Hospitalaria. 2009; 24(1): 56-62.

14. Kementerian Kesehatan Republik Indonesia. Pedoman Proses Asuhan Gizi Terstandar (PAGT). Jakarta: Direktorat Jenderal Bina Gizi dan Kesehatan Ibu dan Anak Kementerian Kesehatan RI; 2014; 15-16.

15. Madrono AG, Mancha A, Rodriguez FJ, Ulibarri JL, and Culebras J. The Use of Biochemical and Immunological Parameters in Nutritional Screening and Assessment. Nutricion Hospitalaria. 2011; 26(3): 
594-601.

16. Cabrerizo S, Cuadas D, Gomez-Busto F, ArtazaArtabe I, Marín-Ciancas F, and Malafarina V. Serum Albumin and Health in Older People: Review and Meta Analysis. Maturitas. 2015; 81(1): 17-27.

17. Laky B, Janda M, Cleghorn G, and Obermair A. Comparison of Different Nutritional Assessments and Body Composition Measurements in Detecting Malnutrition among Gynecologic Cancer Patients. The American Journal of Clinical Nutrition. 2008; 87(6): 1678-1685.

18. Hernandez JA, Vila MP, Sanz ML, et al. Prevalence and Cost of Malnutrition in Hospitalized Patients: the PREDyCES Study. Nutricion Hospitalaria. 2012; 27(4): 1049-1059.

19. Pereira MAC, Santos CA, Barito JA and Fonseca J. Scored Patient-Generated Subjective Global Assessment, Albumin and Transferrin for Nutritional Assessment of Gastrostomy Fed Head or Neck Cancer Patients. Nutricion Hospitalaria. 2014; 29(2): 420426.

21. Susetyowati. Pengaruh Proses Asuhan Gizi Terstandar Berbasis Skrining terhadap Outcome Pasien di Rumah Sakit. [Disertasi]. Fakultas Kedokteran Universitas Gajah Mada, Yogyakarta. 2013.

20. Harimawan AIW, Hadi $\mathrm{H}$ dan Susetyowati. Kajian Metode Subjective Global Assessment (SGA) dan Nutrition Services Screening Assessment (NSSA) sebagai Prediktor Lama Rawat Inap dan Status Pulang. Jurnal Gizi Klinik Indonesia. 2011; 7(3): 99106.

22. Herawati, Triwahyu dan Alamsyah A. Metode Skrining Gizi di Rumah Sakit dengan MST Lebih Efektif dibandingkan SGA. Jurnal Kedokteran Brawijaya. 2014; 28(1): 68-71.

23. Barker LA, Gout BS, and Crowe TC. Hospital Malnutrition: Prevalence, Identification and Impact on Patients and the Healthcare System. International Journal of Environmental Research and Public Health. 2011; 8(2): 514-527.

24. Nourissat A, Mille D, Delaroche G, et al. Estimation of the Risk for Nutritional State Degradation in Patients with Cancer: Development of a Screening Tool Based on Results from a Cross-Sectional Survey. Annals of Oncology. 2007; 18(11): 1882-1886.

25. Shaw C, Fleuret C, Pickard JM, Mohammed K, Black $\mathrm{G}$, and Wedlake L. Comparison of a Novel, Simple Nutrition Screening Tool for Adult Oncology Inpatients and the Malnutrition Screening Tool (MST) against the Patient-Generated Subjective Global Assessment (PG-SGA). Support Care Cancer. 2015; 23(1): 47-54.

26. Demir MV, Tamer A, Cinemre H, Uslan I, Yaylaci S, and Erkorkmaz U. Nutritional Status and Laboratory Parameters among Internal Medicine Inpatient. Nigerian Journal of Clinical Practice. 2015; 18(6): 757-761.

27. Ordonez AM, Schieferdecker MEM, Cestonaro T, Netto JC and Campos ACL. Nutritional Status Influences the Length of Stay and Clinical Outcomes in Hospitalized Patients in Internal Medicine Wards. Nutricion Hospitalaria. 2013; 28(4): 1313-1320.
28. Tsaousi G, Panidis S, Stavron G, Tsouskas J, Panagiotou D, and Katzampassi K. Prognostic Indices of Poor Nutritional Status and Their Impact on Prolonged Hospital Stay in a Greek University Hospital. Hindawi Publishing Corporation BioMed Research International. 2014; 2014: 1-8.

29. Gupta D, Lammersfeld C, Vashi PG, Dahlk S, Grutsch $\mathrm{JF}$, and Lis CG. Is Serum Albumin an Independent Predictor of Survival in Ovarian Cancer? Clinical Ovarian Cancer. 2009; 2(1): 52-56.

30. Virtuoso-Junior JS, Tribess S, Romo-Perez V, and Oliveira-Guerra R. Factors Associated to Risk Malnutrition amongst Elderly Women in Low Income Communities. Colombia Medica. 2012; 43(1): 54-62.

31. Ishida S, Hashimoto I, Seike T, Abe Y, Nakaya Y, and Nakanishi H. Serum Albumin Levels Correlate with Inflammation rather than Nutrition Supply in Burns Patients: A Retrospective Study. The Journal of Medical Investigation. 2014; 61(3-4):361-368.

32. Basu I, Subramanian P, Prime M, Jowett C, and Levack B. The Use of Biochemical Parameters as Nutritional Screening Tools in Surgical Patients. Surgical Science. 2011; 2: 89-94.

33. Gupta D and Lis CG. Pretreatment Serum Albumin as a Predictor of Cancer Survival: A Systematic Review of the Epidemiological Literature. Nutrition Journal. 2010; 9(69): 1-16.

34. Laky B, Janda M, Chennakesavan SK, Cleghorn G, and Obermair A. Pretreatment Malnutrition and Quality of Life-Association with Prolonged Length of Hospital Stay among Patients with Gynecological Cancer: A Cohort Study. BioMed Central Cancer. 2010; 10(232): 1-6.

35. Menteri Kesehatan Republik Indonesia. Peraturan Menteri Kesehatan Republik Indonesia Nomor 28 Tahun 2014 tentang Pedoman Pelaksanaan Program Jaminan Kesehatan Nasional. Jakarta: Berita Negara Republik Indonesia: 2014

36. Prasetiyo WH. Pengaruh Hasil Skrining berdasarkan Metode MNA terhadap Lama Rawat Inap dan Status Pulang Pasien Lansia di RSUP Dr. Sardjito Yogyakarta. [Tesis]. Universitas Gajah Mada, Yogyakarta. 2010.

37. Lim SL, Lee CJ, and Chan YH. Prognostic validity of 3Minute Nutrition Screening (3-MinNS) in Predicting Length of Hospital Stay, Readmission, Cost of Hospitalisation and Mortality: a Cohort Study. Asia Pacific Journal Clinical Nutrition. 2014; 23(4): 560-566.

38. De Luis DA, Terroba MC, Cuellar L, et al. Association of Anthropometric and Biochemical Markers with Length of Stay and Mortality in the Hospital. European Review for Medical and Pharmacological Sciences. 2013; 17(10): 1321-1325.

39. Arques S, Roux E, Stolidi P, Gelisse R, and Ambrosi P. Usefulness of Serum Albumin and Serum Total Cholesterol in the Prediction of Hospital Death in Older Patients with Severe, Acute Heart Failure. Archives of Cardiovascular Disease. 2011; 104(10): 502-508.

40. Wartawan IW. Analisis Lama Hari Rawat Pasien yang Menjalani Pembedahan di Ruang Rawat Inap Bedah Kelas III RSUP Sanglah Denpasar Tahun 2011. [Tesis]. Universitas Indonesia, Depok. 2012. 
41. Anggraini D. Perbandingan Kepuasan Pasien Gakin dan Pasien Umum di Unit Rawat Inap RSUD Budi Asih
Tahun 2008. [Tesis]. Universitas Indonesia, Depok. 2008. 